\title{
"Que los indios no puedan vender sus hijas para contraer matrimonio": Understanding and Regulating Bridewealth and Brideservice in the Spanish Colonial Period of the Philippines
}

\author{
Marya Svetlana T. Camacho
}

In his seminal work on the process of hispanization in the first century and a half of Spanish rule in the Philippines, John Leddy Phelan concluded that the Spaniards had succeeded in Christianizing matrimony; however, he acknowledged that socioeconomic aspects of prehispanic marriage persisted in the first century of Spanish colonization, particularly those of brideprice and bride-gift. According to Phelan, these practices "smacked of fathers selling their daughters, perhaps against the latter's will, to the highest bidder". ${ }^{1}$ While Phelan differentiated between dowry and brideprice as Philippine indigenous practices, an examination of Spanish sources, ethnographic and otherwise, shows that what the Spaniards called 'dowry' (dote) corresponds to brideprice; that is, these two marriage prestations were actually the same. The application of European nomenclature obscured the meaning of the original indigenous referent (bugay in Bisaya and bigay-kaya in Tagalog, two Philippine languages), and so, like early modern Spanish authors in the field, Phelan appears to have confused these terms.

This chapter problematizes the conceptual translation of indigenous marriage prestations. It explores the perspectives of moral theologians and clergymen, and traces the normative means, both ecclesiastical and secular, and their juridical and moral underpinnings, to make native customs conform to Catholic matrimonial law and values. Likewise, it examines normative literature and judicial sources to discern the indigenous response to these efforts at transformation in the late 17 th to 18 th century. In sum, it traces the ways in which the institutions of bugay/bigay-kaya were practised, interpreted, contested, and integrated into the colonial matrimonial order.

1 Phelan, The Hispanization of the Philippines, 64-65. 
Alain Testart's historical study on the shift from bridewealth to dowry among Indo-Europeans provides a theoretical lead. Having established the antiquity of bridewealth practiced alone or in combination with dowry, he attributes the wide-ranging change to ideologies, which includes religions and colonization. He states that Christianity "seems to have always considered bridewealth an anti-Christian institution". ${ }^{2}$ The issues surrounding marriage endowments in the colonial Philippines appeared in the context of the introduction of Tridentine canonical marriage.

Ultimately, the question arises as to how closely the level of efficacy of the legal mandate to do away with bridewealth and brideservice was tied to the level of enforcement of the various laws and directives on the ground, taking into consideration the goals of the cura animarum (the care of souls) and experiential knowledge of indigenous culture and norms concerning marriage. At the end of the 18th century, Spanish colonial authorities continued to decry bridewealth and brideservice, indicating that these persisted, counter to the general tenor of secular and ecclesiastical prescriptions. This chapter deals with these questions. From a mainly anthropological perspective, the chapter begins with a short discussion of the meaning and functions of bridewealth and brideservice (alternate terms for brideprice and bride-gift) in different contemporary and historical societies in the world, and provides background to the ethnographic descriptions of Philippine indigenous marriage prestations in Spanish sources from the early modern period. This is followed by a summary of Castilian law regarding arrhae and dowry as the historical legal context for the interpretation of these institutions. The rest of the chapter consists of a historical outline of how bridewealth and brideservice were dealt with in legal texts and pragmatic normative literature in the Philippines, which naturally drew from the European and Catholic tradition. Although too few exist on which to base conclusive observations about judicial treatment of marriage prestations in the period covered, some 18th-century ecclesiastical court cases from Manila furnish specific details and afford an idea as to the extent in which they were regulated and subjected to either civil or ecclesiastical jurisdiction in various parts of the island of Luzon.

\section{Meanings of Bridewealth and Brideprice}

Before proceeding to the historiography of bugay and bigay-kaya in the earlier centuries of Spanish colonization, this section examines the nature of

2 Testart, "Reconstructing Social and Cultural Evolution", 41. 
this marital institution drawing from contemporary scholarship that has used interdisciplinary methodology, thereby discerning meanings that transcend the understanding of European authors from the early modern period. The abundant literature on brideprice, bridewealth, brideservice, bride-gift, and dowry provides a comparative base that is geographically broad and longitudinal in some cases, albeit covering mainly Indo-European and African societies and generally excluding Austronesian cultures to which Philippine peoples belong. ${ }^{3}$ Since these studies use a combination of anthropological, economic, and historical lenses, they are able to penetrate the intricate meanings as well as the multiplicity of factors affecting the prevalence of some forms of marriage prestations within a given society, as well as changes in them over time. Economic anthropology, in particular, has sought to explain the trends and prevalent forms of marriage transactions. ${ }^{4}$ In addition, the literature allows conceptual comparisons that enrich the interpretation of comparable Philippine practices.

At the outset, the two related problems experienced chiefly in the colonial encounter, which Stanley J. Tambiah has identified, are taken into account. The first pertains to translation, i.e., assigning an English word to a local custom or institution that the writer or observer thinks he has sufficiently comprehended. The second is the unquestioned application of an anthropological category to the phenomenon, which turns out to be inadequate. ${ }^{5}$ Thus, in this paper, the term 'brideprice' as well as 'dowry' are retained when used by the European colonial writers cited, to remain consistent with how they construed the referred marriage transaction.

In all other cases, 'bridewealth' will be used following the same reasoning as Edward E. Evans-Pritchard who maintained his preference for it over other terms denoting marital endowments in non-European societies and for which no English expressions correspond exactly. ${ }^{6}$ This term is also in accordance with the practice prevalent in Philippine elite marriages as described below. Evans-Pritchard demonstrated that it better captured the range of socioeconomic functions and the significance of the institution without ignoring its economic value, while other terms focused only on one aspect. He therefore proposed it as an alternative to brideprice to de-emphasize the notion

3 Goody and Tambiah, Bridewealth and Dowry; Tambiah, "Bridewealth and Dowry Revisited"; Botticini, "Why Dowries?"; Testart, "Reconstructing Social and Cultural Evolution".

4 Bossen, "Toward a Theory of Marriage”; Botticini “Why Dowries?"; Anderson, "The Economics of Dowry and Brideprice".

5 Tambiah, "Bridewealth and Dowry Revisited", 414.

6 Evans-Pritchard, "An alternative term for "bride-price". 
of purchase while maintaining continuity with that long-established term by emphasizing the role of the woman, instead of opting for a more general term like 'marriage-wealth'?

Since Evans-Pritchard, anthropologists have made further conceptual distinctions. Beyond the civilizational and moral connotations of brideprice that earlier debates dealt with, bridewealth and brideprice have been differentiated in socioeconomic terms. Both are understood as a transaction between the groom's and bride's kin, in the direction of groom to bride. ${ }^{8}$ The dynamic of kinship involvement and interest in the transmission of resources elucidates the Philippine practice of bridewealth historically considered below. In relation to bridewealth, Jack Goody created the notion of 'indirect dowry', by which gifts from the groom are received by the bride's father who eventually gives them to his daughter. Further research on pre-colonial Philippine bridewealth might find this a useful category as there is evidence that the bride possessed personal property inherited from parents.

Similarly grappling with the problem of translation of European terms, Bernard Vroklage tested whether brideprice and dower were synonymous concepts in Indonesia. He studied them through the indigenous meanings of the words associated with the corresponding practices and discovered that the indigenous terms equivalent to price and purchase in relation to marriage were not to be understood literally. While material value was indeed involved, and the relevant terms connoted the economic dimension, the woman was not a commodity of exchange per se. Instead, the brideprice was understood as a form of compensation for the cost (economic and otherwise) of the care of the bride-whose marriage represented the loss of a worker and a bearer of children - as well as for the sadness of parting. As compensation, it was not to be conflated with purchase, which implied subordination. Furthermore, the bride's family gifted their in-laws in turn, without seeking to match the value of the brideprice, as an expression of the social value of reciprocity. Vroklage concluded that various Indonesian ethnic groups had as complementary practices what would correspond to brideprice and dower which were very similar to Philippine marriage prestations under discussion here. ${ }^{9}$

7 Subsequent studies on indigenous societies made further inroads into comprehending the range of meanings and functions of these marriage transactions. For example, L. Bossen ("Toward a Theory of Marriage") points to the limitations of transaction terminology often applied to brideservice, bridewealth, and dowry, and the need to include women's economic interests in marriage transactions.

8 See J. Goody, Bridewealth and Dowry, 2.

9 Vroklage, "Bride Price or Dower", 135-137. 
In her study on marriage in a highland community in Guatemala, Laurel Bossen outlined the economic implications of bridewealth. As in Indonesia, it was understood as compensation to the woman's family for raising her and for the loss of their daughter's economic contribution through her work. While bridewealth was a deterrent to separation for the man, it likewise guaranteed sustenance for the woman in case the marriage failed. Having afforded her family some economic advantage through the bridewealth received, she expected them to provide for her should she have to return to the family home. Lastly, bridewealth was the means by which parents arranged a wife for their son, who would contribute economically to the household through her work in partnership with her husband and in assistance to her mother-in-law in domestic tasks. ${ }^{10}$

In the context of maritime Southeast Asia, using archaeology and ethnohistory, Laura Lee Junker compared bridewealth as a normative practice among different ethnolinguistic groups and traced its continuance among non-Christianized indigenous groups in the Philippines today. Bridewealth payments were among the social prestige- and political power-building transactions that members of the elite performed and were an effective way of transferring luxury goods, obtained by local production, trading, or raiding." In this connection, Fenella Cannell analyzed the initial stage of pre-colonial Visayan marriage arrangements thus: "the logic of courtship and brideprice suggested that the bride's side were in fact superior to the groom's side". ${ }^{12}$ Bridewealth fulfilled the function of establishing equilibrium between the two kinship groups brought together by the marriage as it enabled the groom to match the bride's status. Furthermore, William Henry Scott translated the Visayan bugay as brideprice, citing three reasons for differentiating it from the Spanish dowry (dote): its size and kind was set by the bride's father, it was not a set value but subject to bargain "like goods in a marketplace," and, once given, it belonged to the woman and her family, not forming part of conjugal property. ${ }^{13}$ The quality of the bugay was a major signifier of the prospective marriage's importance, particularly among people of high status for whom these unions created or strengthened alliances between their kinship groups. In the Tagalog regions the equivalent term was bigay-kaya.

\footnotetext{
10 Bossen, "Towards a Theory of Marriage", 137.

11 Junker, Raiding, Trading, and Feasting, 294-30o.

12 Cannell, Power and Intimacy, 70.

13 Scott, Barangay, 140.
} 

$(1580-166$ o)

The Visayan islands in the central Philippines were the entry point of the Spaniards while the lowlands of the major island of Luzon in the north, where the colonial capital Manila was founded in the Tagalog region, would be the most intensively colonized areas from 1570 onwards. ${ }^{14}$ The main sources about Visayan and Tagalog bridewealth are reports and historiographical works containing ethnographic sections, as well as dictionaries by Spanish authors. Accounts from the late 16th century identified the dote, using the Spanish equivalent of the indigenous institution, as the principal element in arranging marriages among the Visayans, "paid by the husband to the woman", according to the conquistador Miguel de Luarca. ${ }^{15}$ Marriage proposals were normally initiated by the man's father through a representative who approached the prospective bride's father. Referring to the Visayans, but without using the Spanish term dote, the Boxer Codex also mentioned some sort of payment for the bride: "when a man wants to marry off his son to another man's daughter, the two fathers come to an agreement as to what the groom's father will pay for the marriage". ${ }^{16}$ In addition, Juan de Plasencia's relación (report) on the customs of the Tagalogs and Kapampangans (the inhabitants of the region of Pampanga north of Manila) expressed the indigenous practice as dote, never using the vernacular term bigay-kaya. Accomplished upon the order of the Audiencia of Manila, his relación was intended to become the official reference for indigenous customs in litigation involving natives. ${ }^{17}$ Furthermore, 17 th-century lexicons, namely the Visayan-Spanish Diccionario by Alonso de Mentrida and the Tagalog-Spanish Vocabulario tagalo by Francisco de San Antonio, translated

14 Background on the conquest and colonization of the Philippines can be found in Perez (Chapter 3) in this volume.

15 Luarca, "Tratado de las Yslas Philipinas", cap. 10, 83. Luarca's account is dated 1582. "Despues qe ya esta conçertado el casamiento que despues de auerse conçertado en el qual paga el marido a la mugger". Note that Luarca did not mention the corresponding Visayan term bugay.

16 Donoso (ed.), Boxer Codex, 47.

17 Pérez, "Fr. Juan de Plasencia y sus relaciones", 55. Plasencia made the report upon the request of the Audiencia of Manila; he completed it in 1589. See the Audiencia of Manila's resolution of 7 January 1599 (Hidalgo Nuchera, Los autos acordados de la Real Audiencia, 82-83). Consistent with the differentiation he made between dowry and brideprice mentioned above, Phelan (Hispanization of the Philippines [64-65]), notes: "Plasencia's study did not mention bride-service and bride-price. Hence these customs did not come under the protection of the Spanish law courts". 
"bugay" or "bugey" and "bigáy-caya" respectively as dote. ${ }^{18}$ Thus, the usage of dote appears conceptually consistent across the sources for this period.

The ethnographic descriptions in Jesuit writings from the late 16th to mid17th century, which enriched European knowledge of Philippine matrimonial practices, featured the term dote in the same sense. The chronicle of Pedro Chirino (1604) provided the earliest basic account of indigenous marriage, which Francisco Colin (1663) largely drew from while adopting a more juridical approach. Francisco Ignacio Alzina wrote a voluminous and exceptionally perceptive historical and ethnographical account of the Visayans whose chapters on marriage are unparalleled in detail. ${ }^{19} \mathrm{~A}$ layman's publication from the period was Antonio de Morga's Sucesos de las Islas Filipinas with its final chapter-practically an appendix to what was chiefly a historical work-consisting of an ethnography of the Tagalogs, which he took mostly from earlier writers. Since his book was published in Mexico, it presumably circulated more widely in secular circles than the Jesuit publications did. ${ }^{20}$

Naturally, the Western juridical background of these authors structured their approach and description of marriage prestations. Their oftentimes comparative perspectives used canon law and the ius commune as point of reference, with a view to gauging the extent to which the indigenous institution approximated Christian marriage and therefore its aptness for conversion to the same. The Jesuit authors examined Philippine indigenous societies and cultures in the context of the history of civilizations as seen from a Christian and humanistic perspective, applying European standards of human dignity and social interaction as basis for what it meant to be 'civilized.' ${ }^{21}$ On the matter of dote, Chirino cited classic authors such as Boethius who were familiar with similar customs in other nations: they "were accustomed to buy women to marry". ${ }^{22}$ This notion of purchase and commodification would be reiterated in later religious historical works. A few decades later, in the succeeding Jesuit chronicle, Colin specified that such was the practice in Mesopotamia as well as other nations, "as if [they were] selling their daughters". ${ }^{23}$ Similarly,

18 Mentrida, Diccionario de la lengua bisaya; San Antonio, Vocabulario tagalo. Note that most of the Spanish authors, except for Alzina and later on J. F. San Antonio, did not use the indigenous terms for which they used the terminological equivalent of dote.

19 Chirino, Relación de las Islas Filipinas; Colin, Labor evangélica; Alzina, Una ethografía de los Indios Bisayas.

20 Morga, Sucesos de las Islas Filipinas.

21 See Javellana, The Jesuits, 427; Rubiés, "The Spanish Contribution", 442 and 448.

22 Chirino, Relación de las Islas Filipinas, cap. 30, 70. The translation of all Spanish texts except the Boxer Codex in this chapter is mine.

23 Colin, Labor evangélica, lib. I, cap. 16, 1663, 71. Echoing Colin almost a century later, the Franciscan San Antonio (Chronicas, parte I, lib. I, cap. 45, 169) was more biting: "por modo 
Alzina did not mince words, stating that in the Philippine archipelago "more than marrying off their daughters, [they] sell them". ${ }^{24}$ But then he went on to demonstrate that it was not an unusual tradition since it was the practice among the Jews as well as in Asian nations such as China, Japan, and Cambodia. With irony, he noted that in Europe dowries came from the woman's family to help support the cares of marital life (ad sustendam honera matrimonii), while in the Philippines they added to the burden (ad augenda onera).

Predictably, the ability to give bridewealth belonged to the high-status groups (principales), as a function of wealth and prestige. According to Luarca, ordinarily the brideprice amounted to a hundred taels' worth of gold in the form of slaves and household goods, equivalent to 5 oo or 6 oo pesos. Among the abovementioned authors, only he described marriage among the non-elite: the timaguas (timawas) or freemen celebrated in a much simpler manner for lack of means. ${ }^{25}$ With regard to the value of the bridewealth, the Boxer Codex limited itself to stating "a certain quantity of gold or its [corresponding] value; as is best agreed between them according to the status of each one". ${ }^{26}$ Describing the elaborate marriage negotiations among the Visayan elite, Alzina mentioned slaves, gold, and foreign prestige goods such as ceramic plates and metal bells as the usual components of bridewealth. In a society where labor-and not land - was highly prized and could be bought and sold, slaves represented potential for wealth generation, and accordingly carried the greatest value. ${ }^{27}$ Alzina described the protracted process of courtship and the prestige that the negotiating parties accrued when they imparted the value of the bridewealth to the public. ${ }^{28}$ Alzina $^{29}$ and San Antonio ${ }^{30}$ noted that fathers usually asked for the same amount as the bridewealth they had given for their wives; but

de Comercio, vendiendo a la Hija [...] por precio justo". He described Tagalog marriage as it was in the period of contact with observations on how it had evolved since then.

Alzina, Una ethografía de los Indios Bisayas, lib. IV, cap. 12, 233.

25 Luarca, "Tratado de las Yslas Philipinas", cap. 10, 83-84.

26 Boxer Codex, 47.

27 On slaves in pre-Hispanic Philippines, see Scott, Barangay, 133-135; on land and property, 144-145.

28 Only Alzina (Una ethografía de los Indios Bisayas, lib. IV, cap. 12, 233-234) was able to distinguish that in the negotiation of the bugay some items were designated as symbolic and were not actually given ( holog), while there were others to be given during the marriage if at all demanded (lantai), and another part which had to be delivered to the bride's house before the wedding (idadatung or the Hispanized term ipacasal). Alzina commented how important it was for judges as well as clergy to know these differences to be able to resolve quarrels over such matters.

29 Alzina, Una ethografía de los Indios Bisayas, lib. IV, cap. 12, 233.

30 San Antonio, Chronicas, parte I, lib. I, cap. 45, 169. 
not all suitors could match this demand. The bride's side demanded a big sum to maintain its status, while the groom's ability to meet the demands elevated his side. From being initially asymmetrical, their respective statuses reached an equilibrium through bridewealth, and the transference of property could continue after the wedding. ${ }^{31}$

The Spanish chroniclers provide varying though not altogether discrepant details about the bridewealth and accessory gifts for the bride's immediate family, relatives, and other members of the household, even slaves. Their worth depended on the groom's socioeconomic status, and their kind ranged from small valuables to slaves. ${ }^{32}$ The crucial role of kinship solidarity emerges: "the relatives help each other in this manner" 33 ; those who received their share were in turn obliged to contribute to the bugay of their relatives' sons, either in the same amount or more. ${ }^{34}$ Among the Tagalogs, however, the following gifts formed part of the bigay-kaya: panhimuyat or panghimuyat given to the mother as recompense for having raised the daughter and the pasoso (pasuso), denoting the act of suckling, for the wet nurse. These items were non-negotiable even in the absence of the bigay-kaya, so much so that non-fulfillment of these gifts could trigger litigation. ${ }^{35}$ Among the Visayans, the equivalent of panhimuyat was himirao (literally, compensation for the sleepless nights spent in caring for the infant), usually in gold or silver, given to the mother, grandmother, or whoever had raised the woman. Separately from the bugay, the bride's family received gifts from the groom and his kin several more times during and after the wedding ceremony: as the bride left her house and afterwards, when she was to move to her new home, as if to persuade the bride to leave her parents' dwelling and to compensate for the place she was leaving behind. ${ }^{36}$ This spatial representation highlighted that the woman's realm was the house; there she performed her main activities, such as weaving.

$31 \quad$ Cannell, Power and Intimacy, 70.

32 Chirino, Relación de las Islas Filipinas, cap. 30, 70; Colin, Labor evangélica, lib. I, cap. 16, 71; Alzina, Una ethografía de los Indios Bisayas, lib. IV, cap. 12, 233-235.

33 Boxer Codex, 46-47.

34 Alzina, Una etnografía de los Indios Bisayas, 242-243.

35 San Antonio, Chronicas, parte I, lib. I, cap. 45, 168-169.

36 Alzina, Una ethografía de los Indios Bisayas, lib. IV, cap. 12, 235; cap. 13, 237 and 240; Luarca, "Tratado de las Yslas Philipinas", cap. 6, 83. The Visayan term for the high-status bride was binukot which denoted her seclusion in a room, hence the reference to the empty space that her absence created. Cannell (Power and Intimacy, 70) theorized about the representation of space in the paternal home that the bride was leaving. Additionally, as mentioned above, much anthropological literature has explored the economic significance of the woman whose absence would be compensated by bridewealth or brideprice and 
The Spanish authors readily understood that the bugay/bigay-kaya went to the bride's parents and family but they did not wholly grasp the significance of the familial involvement, which anthropologists have studied thoroughly. Generally, they gathered that eventually part of the property was given to the married couple at some vital stage. In the case of betrothals between children, they were given their share once they reached marriageable age or could start living together. Marriage being virilocal, other couples received their share when they began to have children or formed a separate household. ${ }^{37}$ Among the Tagalogs, upon the death of the woman's parents the bigay-kaya was distributed equally among their children like the rest of their property unless they chose to give more to the daughter for whose marriage it was. ${ }^{38}$ If the girl was an orphan, she received it when she married. And yet, as San Antonio derisively observed, her avaricious relatives, who acted as her guardians, and her wet nurse would often claim their share and leave her with nothing. His other objection was that parents spent excessively on the wedding celebration, so that little of the bigay-kaya remained. ${ }^{39}$

These accounts present how central the negotiation of the bridewealth was in arranging marriages, which culminated in a celebration when the parties arrived at an agreement. Among the Kapampangans, "this [bridewealth] was what made the marriage". ${ }^{40}$ In the language of commodification typical of the Spanish authors, the habilin was given as an advance on the bigay-kaya, "as the token given in transactions of sale at the price agreed on, to prevent sale to another [party]". ${ }^{41}$ Plasencia reported that half of the bigay-kaya was given even when the prospective spouses were still children, noting that this matter became complicated in cases when the reneging party had to pay the penalty set, which varied in value depending on the local custom and status of the parties involved. But if after the parents' death one of those betrothed as a child refused to honor the agreement upon reaching marriageable age, the bridewealth was merely returned to the groom's family without imposition of penalty. However, if the parents were still alive, the penalty remained in force since they arranged the marriage in the first place. ${ }^{42}$ Among the Visayans, if

whose presence in the new household would contribute not only in economic terms but also in her childbearing capacity.

37 Luarca, "Tratado de las Yslas Philipinas", cap. 6, 83; Boxer Codex, 46-47.

$38 \quad$ Pérez, "Fr. Juan de Plasencia y sus relaciones", 69.

39 San Antonio, Chronicas, parte I, lib. I, cap. 45, 170. Although he wrote in the 18th century, San Antonio described marriage practices comparing his 'today' with the past, that is, closer to the previous century. Pérez, "Fr. Juan de Plasencia y sus relaciones", 74.

41 San Antonio, Chronicas, parte I, lib. I, cap. 45, 169. 
the man reneged from the marriage already arranged, he lost whatever part of the bridewealth he had already given as a token, since "as they begin to arrange the marriage, they [also] begin to give the dowry". ${ }^{43}$ Hingisul was the penalty that the party who had failed to keep the agreement was obliged to pay in gold, slaves, and other valuables. Alzina observed that in his day, that is, by the mid-17th century, it was enforced less rigorously than in the past. Aware that the penalty for reneging occasioned forced marriages, the clergy tried to limit its application to cases when the party who had broken the agreement had personally arranged it. ${ }^{44}$ All this went in favor of freedom of consent that the Catholic Church required for valid marriage.

The Spanish authors went into detail concerning the bugay or bigay-kaya in case of divorce. Plasencia reported that among the Tagalogs, if the wife initiated the divorce before having children and she intended to remarry after the separation, she returned the bigay-kaya and an additional amount, as a form of penalty, to the husband; otherwise she returned only what she had received from the husband. If it was the husband who asked for the divorce, only half of the bigay-kaya was returned to him. If the couple had children, they inherited the entire bigay-kaya and penalty which the grandparents-or in their absence another trustworthy person-administered in the meantime. Among the Kapampangans, if the wife divorced her husband, she gave him back double the worth of the bridewealth even if the couple had children. ${ }^{45}$

Luarca shifted the attention from the party initiating the divorce to the legitimate causes of divorce and the consequences on the bugay, as recorded in the discourse of the elder presiding at a Visayan wedding:

The man weds the woman but on the condition that if he became wayward and failed to support his wife, she can leave him and not return anything of the 'dowry' he has given her, and she will be free to marry another man; therefore, if she were a vile woman, [the husband] could get back the 'dowry' he gave her, leave her, and marry another woman. Be all of you my witnesses to this agreement. ${ }^{46}$

Morga followed Plasencia, adding that when the cause of separation was the husband's fault, he had no right to restitution of the bigay-kaya. ${ }^{47}$

43 Luarca, "Tratado de las Yslas Philipinas", 83.

44 Alzina, Una ethografía de los Indios Bisayas, lib. IV, cap. 11, 225-226.

45 Pérez, "Fr. Juan de Plasencia y sus relaciones", 69-70, 74.

46 Luarca, "Tratado de las Yslas Philipinas", cap. 10, 83.

47 Morga, Sucesos de las Islas Filipinas, cap. 8, 254: "Apartábanse y disolvían este casamiento por ligeras ocasiones, vista y juicio de los deudos de ambas partes y de los ancianos que intervenían a ello, y entonces volvía la dote recibida al varón, que llaman vigadicaya, si 
Plasencia also recorded the Kapampangan normative practice as regards the destination of the bridewealth upon the death of the wife. If the couple had had no children at the time of the wife's death, it was entirely returned to the surviving husband. But if the couple already had children, whether the children were alive or dead at the time of the mother's demise, only half of the bridewealth was returned to the surviving husband. Plasencia noted that among the Tagalogs, if one of the spouses died less than a year after the wedding without leaving offspring, half of the bridewealth was returned, although more out of compassion than obligation, to the deceased husband's family, or if it was the wife who died, to the surviving husband. ${ }^{48}$

Since Plasencia's relación was intended to be the juridical reference on Tagalog and Kapampangan customs, the dote, as it was described (that is, as bridewealth) would have been recognized in the colonial legal system. ${ }^{49}$ While bridewealth lay outside the jurisdiction of the ecclesiastical tribunal, tasked to implement the canonical form of marriage and promote Catholic matrimonial values, it inevitably surfaced in that forum in relation to promises of marriage. Alzina's occasional mention of his intervention in such affairs provides a glimpse of the special role of the parish priest and provincial vicar as a recognized arbiter in family and community conflicts. He highlighted how important it was for judges as well as members of the clergy to know the nuances of local conventions to be able to resolve quarrels over those matters. His writing reveals that he intervened as parish priest in these issues, discerning when to abide strictly by local normative practice and when to temper it to lessen the economic burden on the groom's kin, as when the bride's family demanded full payment of the bridewealth promised to follow after the wedding, or when the gifts to the bride's relatives came to cost as much as the bridewealth. ${ }^{50}$ The experiences Alzina narrated provide an indication of how the clergy made use of their moral authority, particularly among Christianized groups, not only to introduce and implement Tridentine marriage, but also to shape notions of

no fuese que se apartaban por culpa del marido, que entonces no se la volvían y quedaban con ella los padres de la mujer". Note that Morga mentioned what would be an approximation of the vernacular term (bigay-kaya) which, as mentioned above, Plasencia never did.

48 Pérez, "Fr. Juan de Plasencia y sus relaciones", 69 and 74. San Antonio, Chronicas, parte I, lib. I, cap. 45, 169-170, echoed this point.

49 Here I differ with Phelan (The Hispanization of the Philippines, 64) who, consistent with his differentiation between dowry and brideprice (or bridewealth), states that Plasencia mentioned only dowry (dote) and therefore the colonial legal system did not recognize brideprice.

Alzina, Una etnografía de los Indios Bisayas, lib. IV, cap. 12, 234 and 236; cap. 13, 242. 
justice in the direction of clemency and moderation of greed-in the particular case of bridewealth, in relation to the material advantages accruing from it.

\section{Dowry and Arrha in Castilian Law}

The Spanish authors, mostly missionaries, not only described Philippine marriage, but inevitably - some more than others-interpreted its constitutive elements at the same time. In this dual but overlapping process they used the categories known to them, articulated for the most part in Castilian as well as canon law. Plasencia's report highlighted that the issues and concerns arising from marriage and family, universal institutions in themselves, were familiar to Europeans and therefore lent themselves to being analyzed using European juridical language.

The principal query that emerges from a reading of the chronicles, reports, and other published works from the early colonial period involves the use of dote as a translation of bridewealth. Plasencia plainly stated, "The men give the dowry to the women, which belongs to the women's parents". ${ }^{11}$ While this implies that the direction of the endowment was different from European practice, Alzina was more forthright about it: "contrary to our practice, which is that the bride's father gives the dowry (the general usage in Europe it seems), here he receives it". ${ }^{2}$ Thus, it seems that these authors were using dote in the generic sense of a marriage prestation regardless of the direction of the transmission of property. However, the indigenous institution was not entirely the opposite of the European practice of dowry, which the woman in effect received from her parents, brought to the marriage, and entrusted to her husband while it remained her property; in the case of bridewealth, the bride's parents and kin received it without necessarily giving it to the bride, although indirectly it might contribute to her marriage when spent on preparations. Also, as mentioned above, the couple could be given part of it at a later stage in their married life. Furthermore, the woman's personal inheritance might include some items from the bridewealth.

Spanish authors logically tended to make sense of indigenous practices, concepts, and terms by homologizing them with those that existed in Castilian law. Later, in the 18th century, the Augustinian Casimiro Díaz recalled the debate among moral theologians on whether it was better for the man or woman to give the dote, with the woman's side mustering stronger arguments.

$51 \quad$ Pérez, "Fr. Juan de Plasencia y sus relaciones", 69.

52 Alzina, Una etnografía de los Indios Bisayas, lib. IV, cap. 12, 232-233. 
But he cut himself short by stating that there was no such thing among the indigenous peoples as it was understood in Europe; rather, what existed was the money given by the groom to the bride's parents. ${ }^{53}$ In the continuing discourse on this particular custom, the conceptual correspondence between dote and bridewealth seemed to derive from the appreciation of their common nature as marital endowments, consisting in the transmission of property or money, and was deemed critical to the negotiation of marriage agreements.

The laws governing marriage prestations during the early modern period in Spain evolved from various legal traditions (Germanic, Roman, and canonical) and corpora, successively incorporated into the juridical system. As a feature of the Germanic influence from the Visigothic legal code Fuero Juzgo, in its third book the arrha together with the father's authority over the daughter's marriage figured prominently. The bride's father or mother received the arrha from the groom; in their absence the bride's brothers or closest relatives received it on her behalf (title 1, law 7). The 13th-century Fuero Real, promulgated by Alfonso x el Sabio to implant royal law in the territories where it did not exist, took from the Fuero Juzgo much of its laws on marriage. ${ }^{54}$ It specified that if the girl was not yet of marriageable age, her parents or brothers should keep the arrha intact until she came of age, and should demand it since it was to serve the couple in their marital life (book 3, title 2, law 3). Likewise, neither spouse could dispose of the arrha in their lifetime without permission from the other and upon their death their surviving children would inherit it. The value of the arrha was limited to the value of one-tenth of the groom's property. This law would be reiterated centuries later by a prohibition of its renunciation in the Leyes de Toro (law 50), compiled toward the end of the reign of the Catholic Kings. If the husband died, the woman was granted the capacity to dispose freely of the arrha if she did not have children (FueroJuzgo, book 3, title 1, law 6); otherwise she kept only half of it, as her children had the right to inherit the other half. All this was on the condition of true marriage, indicated by the spousal kiss. This condition did not hold if it was the woman who died; then the arrha wholly went to the children (Fuero Juzgo, book 3 , title 1, law 5). If she died without direct heirs, the arrha was to be returned to the husband or to his closest relatives if he was also deceased (Fuero Juzgo, book 3 , title 1, law 6). Furthermore, the woman could lose the arrha if she committed adultery (Fuero Real, book 3, title 2, law 6). In the medieval legal corpora, the predominance of the arrha is evident, until the Siete Partidas introduced the Roman concept of dowry. ${ }^{55}$

\footnotetext{
53 Díaz, Parrocho de Indios, lib. I. cap. vi, § 8, no. 71, 54r.

54 Fuero Real, xxiv-xxv.

55 Fuero Real, xxv.
} 
The Siete Partidas as royal law drew heavily from the ius commune and relegated local laws to a subsidiary level. In the fourth Partida, which deals with betrothals and marriage, the laws on marriage prestations are found in title 11. Five types of matrimonial endowments were explained: dote, donation propter nuptias, arras, sponsalitia largitas, and spousal gifts (law 1). The first two derived from Roman law; the dote (dowry) was defined thus: "It is something that the woman gives the husband on account of marriage [...] and is in the manner of an endowment with the understanding that it is intended for the support of and assistance to the marriage". ${ }^{56}$ The dowry belonged to the woman although she entrusted it to the husband during the marriage-whose duty it was to preserve it - for her upkeep in case the couple separated or for her children to inherit once she died. The husband, as head of the household, administered the dowry which was meant to serve the marriage (law 7 ). The donatio propter nuptias is "what the man gives the woman on account of marriage $[. .$.$] as an endowment that the man gives the woman because he marries$ her" (law 1). ${ }^{57}$ Although this donation was called arras in Spain, the same law promptly clarified that ancient law had defined arras as an earnest for a marriage promise, so that whichever side failed to fulfill the promise forfeited it. The sponsalitia largitas was described as the gifts that the spouses might give each other before and after the wedding which should be made equally. ${ }^{58}$ The Siete Partidas (law 2) maintained the Visigothic precept regarding the destination of the arrha upon the demise of one of the spouses.

The Leyes de Toro of 1505 compiled Castilian law hitherto in force, which included more aspects of private law in relation to women, particularly as regards legal transactions, inheritance, and property rights, marking a significant advancement as far as women's legal capacity was concerned. ${ }^{59}$ Regarding the arrha (law 51), the woman's right to it, whether she had children or not, was unambiguously recognized, in continuity with Fuero Juzgo. ${ }^{60}$ The Taurine laws echoed the Fuero Juzgo, Fuero Real, and the Siete Partidas, being explicit about betrothal (matrimonio de futuro) or marriage (matrimonio de presente) as the legitimizing factor for ownership of the arrha and other gifts given before the marriage. If the couple separated after the spousal kiss had been given but before marriage was consummated, the woman had the right to half of what the man had given her (sponsalitia largitas); absent the kiss, she did

$56 \quad$ López, Siete Partidas, $29 r$.

57 López, Siete Partidas, $29 r$.

58 López, Siete Partidas, 29v. "las dotes e las donaciones que faze el marido a la mujer, e la muger al marido [...] se pueden fazer ante que el matrimonio sea acabado, o después. E deven ser fechas egualmente".

6o Reiterated in the Nueva Recopilación, lib. 5, tit. 2, ley 3. 
not receive anything, all the gifts being restored to the man's heirs. ${ }^{61}$ If the husband should die after the marriage was consummated and no arrha had been given, the wife retained everything she had received from the husband. If the arrha had been given before the husband died, the woman had 20 days after the husband's heirs asked her to decide which to keep, either the arrha or the other gifts; otherwise the choice was theirs (law 52$).{ }^{62}$

By the early modern period, the arrha had evolved from the Germanic brideprice to become the groom's tribute to the bride's virginity. ${ }^{63}$ The arrha has also been interpreted as the husband's compensation for the marital rights over the wife that he acquired. This understanding of the arrha emphasized conjugal relations in which the importance of the wife was acknowledged even under the husband's dominion, by which marriage formed the core of family. Margarita María Birriel pointed out that despite the Siete Partidas' attempt to equate the arrha with the Justinian donatio propter nuptias defined above, Castilian juridical and notarial practice demonstrated otherwise, a difference which was reinforced in the Leyes de Toro. Nevertheless, the Siete Partidas, which had defined arras in two interrelated ways, became the basic reference for the definition of arras in 16th- and 17th-century Spanish dictionaries. ${ }^{64}$

A summary comparison of women's property rights with respect to the arrha and Philippine indigenous customs regarding bridewealth would yield commonalities particularly regarding the conditions for retaining or losing that marriage endowment as well as the children's right to inherit it. The Spanish authors in the colonial Philippines, however, preferred to use the term dote instead of arras, perhaps influenced by the value of bridewealth in Philippine society which paralleled the crucial importance of the dote in Europe in arranging marriages.

The Nueva Recopilación de las leyes destos Reynos of 1567 , which posthumously fulfilled Queen Isabel's desire to compile and organize Castilian law, included only three laws related to arrhae taken from the Leyes de Toro (and therefore from the earlier codes of law) and a royal decree from 1534 regulating the value of dowries vis-à-vis income levels as well as the sponsalitia largitas, described above. The latter reveals that dowries needed to be regulated so as not to be an unreasonable hindrance to marriage; they had become inflated in their pivotal role in negotiating advantageous matches in the early modern

$61 \quad$ Mijancos (La igualdad entre el varón y la mujer, 138) interprets this measure as a way of protecting women against unfulfilled marriage promises since a spousal kiss received by an unmarried woman was an occasion of dishonor.

62 Reiterated in the Nueva Recopilación, lib. 5, tit. 2, ley 4.

63 Korthe and Flusche, 400.

64 Birriel, "Mujeres y matrimonio", 85-87. 
period, not only in Spain but also in New Spain. ${ }^{65}$ The provisions of the other earlier legal codes in regard to matrimonial property and inheritance continued to be in force. As in Spanish America, the laws of Castile and those promulgated for the Indies, as well as canon law, were applied to marriage in the Philippine colony where, with increasing experience and knowledge of indigenous socioeconomic and cultural institutions, eventually local laws were enacted.

\section{Bugay and Bigay-Kaya in the Framework of European Law: Juan de Paz's Translation}

Some of the abovementioned authors directed their ethnographic writings to aiding judicial and spiritual administration by way of enlightening the Spaniards on indigenous practices and traditions. Although hitherto little is known of the jurisprudence from the period, which may shed further light on how European law grappled with indigenous normative practices, we do have the opinion of Juan de Paz (1622-1698), the renowned Dominican moral theologian in Manila, in a case involving dote. ${ }^{66}$

This case involved Mateo, who gave his betrothed Gerónima 20 pesos as dote and, in addition, promised ten pesos for her wedding dress. They agreed that if Mateo reneged from the marriage, he would forfeit the 20 pesos; if Gerónima did, she should return the same amount and 20 pesos more. In effect, they agreed on penalizing the party who failed to keep the agreement - a practice condemned by ecclesiastical and civil law. On the day of the wedding itself, Mateo brought her a secondhand wedding dress which the bride rejected. He then offered the ten pesos so she could purchase a wedding dress of her choice, but the bride and her parents still refused to proceed with the wedding. In the subsequent litigation, the judge sentenced Gerónima according to the terms of their betrothal, apparently in accordance with the counsel of Paz.

The main argument in the consultation (consulta) about this case was that canon law prohibited imposing a monetary penalty for breaking a betrothal

65 Owens ("El precio de la novia", 28o-281) traces this trend in other parts of western Europe in the same period; on New Spain, see, for example, Gonzalbo Aizpuru, "Las cargas del matrimonio", 210.

66 Against the background of dearth of locally produced jurisprudential works in early Spanish colonial Philippines, Paz's Consultas was exceptional and responded to the need to have a stable corpus of cases for reference, particularly on questions and scenarios specific to the Philippines. Many unpublished consultations on the most varied issues are kept in the Archives of the University of Santo Tomas in Manila. Camacho, "Mirando las cosas de cerca", 271-272, 275. For his earliest known biography, see Salazar, Historia de la Provincia de el Santísimo Rosario, 729-731. 
because the financial burden could constrain the freedom of the reneging party. When asked to clarify the basis for his counsel, Paz cited other authors who held the opinion that imposing a penalty for breaking a marriage promise without reasonable cause was valid, but not in cases of justifiable cause. However, in the present case, Paz argued, what the woman forfeited was the arras and not the dote, and therefore the judge's decision lay within the bounds of law. The arrha was a sign of future marriage and therefore had to be returned if one of the parties went back on his or her word. ${ }^{67}$

Pursuing his argument, Paz explained that conflating the restitution of the dote, on the one hand, and the restitution of the arrha with an additional amount, on the other, made the sentence seem like a penalty and was therefore in violation of the freedom of marriage. However, the consulta maintained that the 20 pesos that Mateo had given Gerónima was dote and not arras; therefore, the additional 20 pesos the woman had to pay was a form of penalty and had nothing to do with the arras. Paz insisted that the man had given the woman a token of future marriage - the arrha-comparable to a purchase for which an earnest or an advanced amount was given. In the case at hand, the sum of 20 pesos was given as guarantee of future marriage and was thus tantamount to a contract. Regarding the additional 20 pesos paid by the woman, it was in keeping with the significance of the arrha; civil law penalized the woman who broke the betrothal by obliging her to return double the value of the arrha, which at any rate was usually less in value than the dowry. ${ }^{68}$ Clearly, Paz chose to be guided by the Siete Partidas, whose definition of arras he used. The influence of the ius commune is evident in his argumentation on penalties for broken marriage promises while safeguarding the freedom of marriage, for which he relied heavily on the Justinian Code and canon law.

Paz's opinion would resonate with Pedro Murillo Velarde's in his Cursus Juris Canonici, Hispani et Indici published decades later (1743), in which arrha was unambiguously defined as a sign and token of marriage and could be given by both man and woman to each other. When applied to a marriage promise, however, it constituted a penalty imposed on the reneging party; as such it was merely promised and not given and usually amounted to more than the arrha so that it would be more obliging. Absence of a legitimate reason for not fulfilling the marriage promise justified the imposition of penalty without impairing the freedom of matrimonial consent. ${ }^{69}$

\footnotetext{
$67 \quad$ These connected cases are presented consecutively in the chapter Tercera clase (Simples promesas, mandatos, fideicomisos) as Consultas III, IV, and v (Paz, Consultas y resoluciones, 280-283).

68 Paz, Consultas y resoluciones, 282-283.

69 Murillo Velarde, Curso de derecho canónico, lib. 4, tit. 1, nos. 9 and 10.
} 
The abovementioned case evinces the degree of confusion about indigenous marriage prestations and the terms applied to them, and, as Paz pointed out, the need to clarify concepts. The term dote was used to denote the sum given to the woman, which in accordance with indigenous norms was received by her parents; to jurists familiar with native Philippine culture, the referent of the translation would be distinct enough. Paz, then, homologized European and Philippine practices by translating the native bugay/bigay-kaya as the European arrha by virtue of the fact that the groom provided it. While in this way he respected the prevailing indigenous norm, he emphasized the meaning of the sum of money that Mateo had handed to Gerónima's parents: that it was a sign of commitment of both parties to marriage, serious enough to justify the imposition of a penalty without violating the freedom of marriage of the betrothed. He did not nullify the local customs which the litigating parties were following, and which penalized the breaking of marriage promises. However, by framing the case in Castilian law and translating indigenous notions into European categories, he focused on the meaning of arrha, which he qualified as more than merely a promise, and therefore justified the penalty.

Since this case was limited to the concept of arrha, it is unclear whether Paz complemented the translation of the bugay/bigay-kaya to arras with a corresponding concept for the Spanish dote, that is, for what the bride's family might give to the bride or to the couple. Except for Alzina, it seems that little or no attention was paid to a possible indigenous equivalent of the arrha understood as donatio propter nuptias, called bantal, which in olden times was expected to be double the bugay. Paz did not adequately capture the sociocultural meaning of the bugay/bigay-kaya in indigenous society — and it would be too much to ask of him to have known what modern anthropology has learned-when he limited his analysis to the meaning of arrha as an earnest. The impact of his legal translation on colonial jurisprudence and subsequent cases has yet to be verified. What is clear in the ecclesiastical and civil sources of the 17th and 18th centuries is that the term dote continued to be employed in the same sense as it had been used earlier by Plasencia and other authors during the early colonial period.

\section{Dote and Servicio Personal in the Normative Discourse of the 18th Century}

Although churchmen in the Philippines had long been cognizant of the effects of indigenous marital prestations considered detrimental to canonical marriage and had taken steps to mitigate them, the publication of the Recopilación de de las leyes de Indias in 1681 furnished colonial authorities with a firm secular 
basis for the reform of those customs. They found an apposite regulation in book 6, title 1, law 1, in which they recognized how the Maya categories and socioeconomic context of the original decree were analogous to those found in the Philippines. ${ }^{70}$ From this point of departure, this section traces the history of ecclesiastical and civil legislation forbidding the dote and servicio personal in the 18th century and examines how it was applied through the lenses of litigation revolving around broken marriage promises in the ecclesiastical tribunal, specifically of the archdiocese of Manila. It ends with the colonial Church's endeavor to make marriage conform to Tridentine norms through conciliar and synodal decrees from the 1770s. In the last quarter of that century, the defense of freedom of marriage which lay behind its consistent denunciation of those two indigenous practices again surfaced in response to the royal decrees which strengthened parental authority or its equivalent over the choice of spouse in function of social order.

\subsection{Linking Maya and Philippine Marriage Practices: Religious and Secular Ordinances in the 18th Century}

Servicio personal or brideservice formed part of the bugey/bigay-kaya. Among the Visayans, brideservice (pangagar) of about a year was rendered by the sonin-law even if he had fulfilled the requirements of the bride's parents for the bugay. If he had not, then he served longer. ${ }^{71}$ The groom, while still a minor or while waiting for the bride to come of age, worked for his future in-laws. In other parts, it was a post-wedding obligation with a duration which could range from a few years to a lifetime. It was a practice consonant with the traditional attachment of Visayan women to their family home, obliging the men to present them with gifts at every stage of the transfer to their new home. Although some parish priests found it difficult to curb this custom, considered oppressive, Alzina, with his deep knowledge of the Visayans, conceded that it was not altogether bad as long as it did not prevent the couple from enjoying marital relations. ${ }^{72}$

As to why the other chroniclers appear to have failed to observe the practice of brideservice and therefore made no mention of it is an unresolved question.

$70 \quad$ Recopilación de las leyes de Indias, 190: "Que los Indios no puedan vender sus hijas para contraer matrimonio".

71 Alzina (Una ethografía de los Indios Bisayas, lib. IV, cap. 13, 239-241) traced the etymology of this term to humagar or father-in-law, such that pangagar meant living in the in-law's house, in effect a temporary kind of uxorilocal residence, although in some cases it became permanent.

72 Luarca, "Tratado de las Yslas Philipinas", cap. 6, 83; Alzina, Una ethografía de los Indios Bisayas, lib. IV, cap. 13, 239-240. 
It might be that they had not been sufficiently immersed in indigenous communities to discern that uxorilocal residence after marriage entailed brideservice. For example, if the bride was very young — as young as 12 years old—she was allowed to remain in her parents' home and much time could pass before the marriage was consummated. Alzina's ethnography was exceptional in its depth and breadth of knowledge of Visayan culture and norms, capturing details and nuances that no other missionary writing in the first century of colonization did. But, as will be seen below, the information it offers is not sufficient regarding brideservice.

While in the prehispanic period (continuing until the early colonial period) bridewealth was largely a status-building, alliance-forming practice among the elite, in colonial times it evolved into a generalized practice involving lower values and was more conspicuously accompanied by brideservice. ${ }^{73}$ Although the early accounts were critical of bridewealth and drew attention to the notion of purchase and commodification it connoted, they did not dwell on the moral and canonical arguments that colonial authorities would invoke at the turn of the 17 th century and throughout the 18 th. ${ }^{74}$ Alzina's description of brideservice as a post-marriage tradition diverged from the pre-marriage requirement that was severely disapproved of in the colonial normative order. Available sources do not allow us to establish whether such a change did take place in the 17th century, nor can we readily apply Alzina's observation to the other indigenous ethnolinguistic groups in the Philippines.

The reiteration of arguments from religious faith and morals, with corresponding disciplinary measures, points to an apparent inefficacy of the legal means enacted. The moral reasons for censure appeared repeatedly in secular and ecclesiastical law and in manuals for clergy and moral theological writings, in response to the common concern for public morals understood within the cultural matrix of Christianity. ${ }^{75}$ Manuel del Río summarized the collaboration of authorities thus: "and so the Minister has to be vigilant in this matter, severely punishing those who are guilty of this, or notifying the alcalde mayor [provincial governor], who has been entrusted with this business by virtue of royal ordinances, or the vicar forane to whom this matter closely pertains". ${ }^{76}$

Aside from the licentious premarital relationships that brideservice propitiated, in Parrocho de indios, a manual for parish priests published in the mid18th century, Díaz underlined its serious consequences affecting the freedom

73 Cannell, Power and Intimacy, 74.

74 Garcia, "Particular discipline on marriage", 20-24.

75 Díaz, Parrocho de Indios; Ortiz, Práctica del ministerio; Aust, lib. 62.

76 Río, Instrucciones morales, cap. I, § 6, Del Sacramento del Matrimonio, 1or. 
of marriage. The daughter was especially vulnerable when forced to marry the man whom her parents had chosen because he could afford to give more dote. Díaz clarified this dubium (doctrinal question) following the Tridentine teaching: although children ought to obey their parents' wishes regarding matrimony - to the extent these were reasonable - they enjoyed the freedom to marry whom they chose. He expressed openness to this indigenous custom even though he thought the bride's parents did not need to be compensated for carrying out their natural duties to their offspring, which was the purported rationale of the bigay-kaya. But precisely for the foregoing reasons affecting the validity and integrality of marriage, he included this topic in the chapter on "the abuses and bad habits of Gentilidad" in the celebration of matrimony. ${ }^{77}$

The decree of Governor Domingo de Zabálburu of 8 April 1704 was a collaborative effort with the Archbishop of Manila Diego de Camacho as an attempt to eliminate both bridewealth and brideservice in one sweep. ${ }^{78}$ It cited book 6, title 1, law 1 of the Recopilación de las leyes de Indias, originally decreed by Philip IV for Guatemala (Madrid, 29 September 1628). ${ }^{79}$ It prohibited parents from receiving anything from suitors, whether in money or in kind. ${ }^{80}$ Given the similarity between Maya and Philippine marriage prestations, it is easy to see how colonial authorities appreciated the law's applicability halfway around the world. Like the Spanish accounts of indigenous Philippine cultures, the bishop of Yucatan Diego de Landa's description of Maya matrimonial customs in the mid-16th century used European categories: the parents of the prospective spouses-who were married at the young age of 12 or 13 at the time of Landa's writing - arranged the marriage by agreeing on the dote and arras, which were not much; the former was given by the boy's father to the girl's father, and in addition the boy's mother proceeded to prepare the dowry in the form of clothing for her son and daughter-in-law. After the wedding, the groom remained in the house of his in-laws where he worked for five to six years for his father-in-law. Negligence on his part was reason for his in-laws to make him leave the house and presumably dissolve the marriage. ${ }^{81}$

77 Díaz, Parrocho de Indios, lib. I. cap. 6, § 8, 54v-55r. On the notion of Gentilidade in Portuguese Asia, see Lourenço (Chapter 7 ) in this volume.

78 AUst, lib. 6o, fols. 133v-134r.

79 The royal decree was preceded by the seventh ordinance of those issued by the oidor (royal judge) of the Audiencia of Guatemala Juan Maldonado de Paz on 19 December 1625. Tovilla, Relaciones histórico-descriptivas, chap. 22, De las ordenanzas por hoy se gobierna estos indios de la Verapaz, no. 7 .

8o Modern-day Maya in highland Guatemala continue to practice bridewealth (Bossen, "Towards a Theory of Marriage", 137) the economic implications of which has been explored and may be applied, to some extent, historically.

Landa, Relación de las cosas de Yucatan, chap. 25. 
The Philippine version of the law applied the same penalties as the original to the parents found guilty of admitting the forbidden practices: fifty lashes for the timagua (timawa) (mecegal [macehual] in the original), demotion of the principal to timawa, and ineligibility for public office. ${ }^{82}$ The main motive for enacting the law was stated as follows:

from which [custom] result many grave offenses to God our Lord, against chastity as well as against justice, because oftentimes when the agreement with the indio parents is dissolved, those [men] who were supposed to marry lose the payment due to their work, or of their own free will abandon the indio women who suffer the lamentable loss of their virginity, and the men [the loss of] their labor. ${ }^{83}$

This decree formed part of the ordinances issued by Zabálburu and subsequent governors general of the 18th century, such as Pedro Manuel de Arandía and José Raón. ${ }^{84}$ The Augustinian Tomás Ortiz referred to the specific ordinance in a handbook for his confreres:

The indios have the custom of serving the parents of the woman whom they wish to marry, from which many sins have ensued because that service is usually the proximate occasion [of $\sin$ ] for the two who want to get married and, owing to that, several edicts have been issued to prohibit it. See the royal ordinance no. $42 .{ }^{85}$

This ordinance was among those selected by the alcalde mayor of the Tagalog province of Bulacan for local promulgation in $1733 .{ }^{86}$ The concern for virtue

82 In the socioeconomic hierarchy at the period of contact, which Plasencia described as "estates", the timawa was below the datu (chieftain) or maginoo class; considered as freemen, they were followers of the datu and rendered him services including military. By the 18th century, with the gradual elimination of debt peonage, lowland indigenous society became two-tiered, consisting of the principales who were eligible for public office, and the timawa or commoner. See Scott, Barangay, 219-223.

83 AUST, lib. 6o, fol. 133v.

84 Zabálburu, "Ordinances", The Philippine Islands, 216-217; Aust, Libros 6o, fols. 133-134. In the 4oth ordinance, Zabálburu explained that he had received a communication from the archbishop dated 26 January 1702 asking him to enforce the cited law from the Recopilación de las leyes de Indias. Note, however, the different number cited by Tomás Ortiz and Manuel del Río.

85 Ortiz, Práctica del ministerio, § 7, De la administracion del matrimonio, no. 77, 25. M. del Río, Instrucciones morales, cap. I, §6, Del sacramento del matrimonio, 1or, also refers to the same ordinance.

86 AFIO 88/40, Ordenanzas circuladas por el Alcalde mayor de Bulacan, no. 7 . 
and to maintain freedom of marriage for both men and women also appeared in the ordinances issued for northern Luzon provinces Cagayan (1739) and Ilo$\cos (1743)$ by the oidor of the Audiencia of Manila, Ignacio Arzadun y Rebolledo, resulting from the visita a la tierra that he conducted there. The 33rd ordinance condemned the dote as an abuse because it was set at prohibitively high values which were unattainable for most men, thereby discouraging them from getting married. The law underlined the coercive effect of those practices and applied, like Zabálburu's, the same penalties as the aforementioned law found in the Recopilación de las leyes de Indias, this time substituting the Ilocano term caylian for the Tagalog timawa. ${ }^{87}$

A quarter of a century later, however, Miguel García San Esteban (1768-1779), the bishop of the diocese of Nueva Segovia in northern Luzon, was still decrying this "abuse" which was particularly prevalent—as it had always beenamong wellborn people. He was more explicit in describing the immoral consequences of brideservice of six months to one year or more, which among other things delayed marriage:

oftentimes after a long service causing grave damage to his property, and greater [still] in his soul, he is dismissed on account of a small fault, and they withdraw from the wedding that was already arranged, and in this way parents convert their daughters into prostitutes, and sell them [...] [which] matters little to them, and they take no notice of the taint on their honor even if their daughter may have lost her maidenhood, becoming a most corrupt woman, not a woman for holy matrimony but [instead] a harlot exposed to reproach and ridicule. ${ }^{88}$

Bishop San Esteban was aware how difficult it was to extirpate these practices since the natives took care to hide them from the Spanish authorities. In his pastoral letter, quoted above, he prohibited prospective grooms from going to the woman's house for any reason after their betrothal until their wedding day. If necessary, the woman should live in another house where such separation could be guaranteed.

In the diocese of Nueva Caceres in southeastern Luzon (Bicol region) a series of ordinances condemning bridewealth and brideservice was issued. The pastoral letter of Isidro de Arévalo of 1746 compiled the ordinances and decrees issued by his predecessor Felipe de Molina in 1724, who in turn had

87 APD, 1/79, Pangasinan, tomo 9, doc. 7 , fol. 171 .

88 AUST, Libros 27, fol. 157r. 
cited Domingo de Valencia's ordinances of $1717{ }^{89}$ Bishop Valencia referred to Bishop Andrés González's 1684 ordinance prohibiting and imposing fines on servicio personal and broken marriage promises owing to the inability to provide the marriage prestation. ${ }^{90} \mathrm{He}$ reasoned that if canonical marriages did not take place, cohabitation consequently increased. González had likewise prohibited the practice of gifting the mother. In addition, in a radical move subverting the age-old conception of brideprice, the bishop attempted to transform bridewealth into the European notion of donatio propter nuptias, which was to be given to the parents of the bride a few days before the wedding, with guarantors to ensure that the entire amount should be given to the couple upon marriage. The point of these rules was to prevent the bride's parents and their relatives from consuming the gifts and money from the groom, a scenario that had led more than one family to force their daughter into marriage "so that without freedom, they contract an act which needs to be very voluntary". 91 To enforce this new norm, aside from requiring that the gifts be exhibited, the bishop stipulated fines, part of which was to be awarded to the denouncer. The responsibility for implementing these rules fell to parish priests. So far, there is no evidence to indicate that this particular mandate was observed.

The Archbishop of Manila, Pedro de la Santísima Trinidad Martínez de Arizala, issued his own ordinance in 1751 . He also castigated brideservice, devoting an entire section to it, in which he blamed the clergy for not being zealous enough in their efforts to eliminate the practice. He directed the parish priests to collaborate with the town elite and alcaldes mayores to exclude violators from the nomination lists for public office. He also targeted the parents, and not the men who complied with the required service to be able to win their brides, as the main culprits. As it would stain their honor, Martínez de Arizala thought this course of action could more effectively deter the principales from demanding brideservice. In this respect, he echoed the tenor of the original legal source from Guatemala found in the Recopilación de las leyes de Indias. With his determined stance, the Archbishop instructed the parish priests to notify him should such a measure prove ineffectual, in which case he would threaten deportation to Zamboanga in the far south of the Archipelago. ${ }^{92}$

\footnotetext{
89 AUST, Libros 27, fols. 179-26o.

$90 \quad$ AUST, Libros 27, fols. 205r-v.

91 AUST, Libros 27, fols. 207v-208r.

92 Santísima Trinidad, Carta pastoral, 19-33.
} 


\subsection{Enforcing Marriage Practices: Litigation over Broken Promises of Marriage}

The evidence about the implementation of these rules remains anecdotal. The Franciscan parish priest of the Tagalog town of Baras in the archdiocese of Manila, Casimiro Pitarque, remitted to the diocesan tribunal a case of an unfulfilled betrothal. In the testimonies gathered, the purported cause was Servando de los Santos' omission: he was unable to help finish building his future in-laws' house as an expected part of the brideservice. From Pitarque's point of view, the betrothed daughter was simply obeying her father in all this. Servando had rendered service indirectly by hiring laborers to work in the fields on his behalf and by providing provisions and construction materials. He claimed to have done that to avoid the penalties for violating the prohibition of servicio personal, for which Pitarque cited the relevant law from the Recopilación de las leyes de Indias, the $175^{1}$ pastoral letter of Archbishop Martínez de Arizala, and several orders of alcaldes mayores. Pitarque explained that in 1777 he himself had urged the local authorities to enforce the law strictly and since then a few violators had been punished. To encourage persons to confess violations, four years later an additional provision stipulated that in case of an aborted marriage, the person who owned up would not be punished. In a tone of resignation, the parish priest admitted that these practices were so deeply rooted that it was not enough to preach against them, "so it is necessary to accompany the bread of doctrine with the stick of chastisement". 93

An initial analysis of the pronouncements of ecclesiastical authorities and the admonitions of clergymen vis-à-vis the concerns of litigants in lawsuits revolving around broken promises of marriage shows the gap between the ideal and the reality. On the one hand, the laws decried the moral consequences of the controverted marital prestations, conveyed as permanently detrimental to individual and family integrity and to canonical marriage. On the other, unfulfilled betrothals could in reality be threshed out with economic compensations and other forms of censure and satisfaction contemplated in canon law. ${ }^{94}$ The person who reneged from the marriage promise without

93 AAM, Informaciones matrimoniales, 14.A.3, fold. 12 (a). The series labeled as 'Informaciones matrimoniales' contains various types of documents, not only pre-matrimonial information declaring that the contracting parties were free to marry. The bulk of the records consist of records of matrimonial cases brought before the ecclesiastical tribunal, and of them a good number revolved around broken marriage promises. Unfortunately, none of them include legal opinions and references to legislation considered in the formulation of verdicts and sentences.

94 Murillo Velarde, Curso de derecho canónico, lib. Iv, tit. 1, De los esponsales y matrimonios, no. 7 . 
justifiable cause would be penalized: the giver lost the arrha and the receiver restituted double its value. ${ }^{95}$ Thus the bulk of court proceedings consisted in establishing whether the litigants — or their parents—-had mutually made that promise, especially when a third party was involved or the woman had become pregnant. Canon law admitted a wide range of signs of betrothal, open to local conventions and various circumstances, which were applicable to indigenous matrimonial culture. ${ }^{96}$

In the third quarter of the 18th century, servicio personal was still presented as evidence for the existence of a betrothal, which was binding in conscience, in ecclesiastical judicial proceedings in the archdiocese of Manila. In Ignacio Flores's pursuit of the fulfillment of his betrothal to Nicolasa Pagtachan, he mentioned the three years of service that he had rendered as proof. He concluded that Nicolasa had been forced to belie their engagement when her parents changed their mind, seeing the little advantage they could gain from having him as a son-in-law. ${ }^{97}$ Brideservice was also presented as secondary evidence to the principal cause of litigation, when the complainant demanded restitution following a broken promise of marriage. ${ }^{98}$ The witnesses from the community of the litigants took for granted that servicio personal as a matter of tradition was a true signifier of a marriage agreement. ${ }^{99}$ Its absence could likewise be used as an argument as it was in the case of Gerónimo Bernabé who wished to suspend his daughter María's marriage to Manuel: "he [Manuel] had never been to the house of the person I represent, nor performed any personal service there, neither has the aforementioned man communicated by himself or through his elders about his aforementioned aspiration". 100 Thus, the lack of servicio personal signaled that no marriage had been agreed upon.

The tribunal did not accuse the litigants of violating the law against brideservice but adhered to the core issue of determining whether the betrothal existed in the first place or a just cause for breaking the marriage promise could be proven. Similarly, records show how traditional it was for the man to give foodstuff and other goods to the woman and her parents and for their household. These gifts would have been more akin to the sponsalitia largitas; there was an unspoken understanding that those tokens were traditional

95 Murillo Velarde, Curso de derecho canónico, lib. IV, tit. 1, De los esponsales y matrimonios, no. 9.

96 Murillo Velarde, Curso de derecho canónico, lib. Iv, tit. 1, De los esponsales y matrimonios, no. 4.

97 AAM, Box 14.A.2, fold. 4.

98 AAM, Informaciones matrimoniales, 14.A.3, fold. 12 (b); 14.A.3, fold. 3 .

99 AAM, Informaciones matrimoniales, 14.A.2, fold. 4; 14.A.3, fold. 13, fols. 7 and 9; 14.A.3, fold. 1.

100 AAM, Informaciones matrimoniales, 14.A.3 fold. 14. 
manifestations of the man's abiding intention to pursue marriage. ${ }^{101}$ If a party desisted from the marriage, the question of restitution of the gifts and compensation for brideservice came to the fore.

Juan Manuel Pérez, a principal of the town of Malate, a suburb of Manila, demanded that the wedding of his son take place after the stipulated period of servicio personal. Suspecting that the other party was going back on their word, Pérez presented a list of the expenses incurred by his son, consisting of gifts and farming needs such as a plow, seeds, laborers' wages, and rental fees for carabaos, and, at the end of the list, "the seven months, more or less, that my son worked in their house (priceless)".102 Even then, the other party insisted on another year of service. A similar case was brought to the ecclesiastical court by Patricio Xavier, native of Taguig, a town east of Manila. The parents of Maria Candelaria refused his suit, but he claimed that the girl had already promised to marry him. To substantiate his demand, he presented a long list of items, mostly foodstuff and building materials, including details of the manual work he had rendered around the house. Many of the items had been given upon the request of his future in-laws, but the latter only admitted to having received some of the items, which they were willing to reimburse. ${ }^{103}$ Unfortunately, none of the cases of the latter kind were resolved on record, nor are there notations in that regard, perhaps signaling that it was to be settled in the secular court or extrajudicially.

Maria Rita de Rivera resorted to the legislated prohibition of brideservice to liberate herself from Vicente Hernández, whom her father wanted her to marry. When witnesses testified that Vicente had been staying in their house, they were implying that he had rendered the customary brideservice. Maria Rita argued that he should be punished for having performed an unlawful act, thereby leaving her free to marry the man to whom she was truly engaged:

Because it is the usual way of contracting betrothals among the natives to begin with personal service, both harmful and prohibited with many penalties, which Your Honor knows, and that its transgression favors my freedom's rights. ${ }^{104}$

Regarding broken marriage promises, the partnership between secular and ecclesiastical jurisdiction theoretically corresponded to a division in jurisdiction, with the demands for restitution and compensation being pursued before 
civil authorities such as the town gobernadorcillo in the first instance. However, on the ground, this jurisdictional division was not always as unambiguous. ${ }^{105}$ The ecclesiastical court was principally concerned with establishing the veracity of promises and mutuality of consent, in which the material aspects played a central role, examining the litigants' willingness to honor betrothals and imposing the appropriate sentence for those who unjustifiably reneged, which included economic compensations for the wronged party. In accordance with canon law, the parties who reneged without just cause were admonished with a view to compelling them to proceed with marriage; in cases of firm refusal, the judge did not risk leading them into an unhappy marriage and settled the case by dispensing other forms of satisfactory justice. Censuring the reneging party was not considered an attempt against their freedom which they had already used irresponsibly; as Murillo Velarde affirmed, "such fear is not unjustly inflicted, but rather justly, and therefore is not harmful to marriage".106 Thus, in the lawsuits concerning betrothals the basic prescriptions of canon law were applied regardless of the ethnicity of the litigants.

The handful of cases involving brideservice indicates that the repeated legal dispositions to stamp it out did not effect radical changes on the micro-level of villages and towns, even up to the latter half of the 18th century. Whether the 1782 case from Baras signaled the strengthening of legal force cannot be concluded in the absence of more cases. Moreover, at the turn of the 18th century, the persistence of the bigay-kaya and other gifts, with the same spending patterns associated with them, was still reported and repeatedly denounced by churchmen.107

\subsection{Instituting Tridentine Marriage through Ecclesiastical and Royal Regulation}

The colonial Church consolidated its pronouncements on the sacrament of matrimony in the first Provincial Council of Manila and the Synod of Calasiao in the province of Pangasinan in the suffragan diocese of Nueva Segovia. The first was held in 1771, almost two centuries after the creation of the ecclesiastical province, as part of the implementation of Charles III's 1769 decree to hold

105 AUST, Pangasinan 3, rollo 5o, no. 14. The confusion in the realm of implementation was exemplified by a woman's appeal regarding a broken marriage promise and her demand for restitution of gifts, addressed to the alcalde mayor of the province of Pangasinan in northern Luzon. Having been first arraigned in her town, she was told afterwards by the escribano in another town that her case belonged to the ecclesiastical jurisdiction. She ended up subjected to public penance by the vicar forane.

106 Murillo Velarde, Curso de derecho canónico, lib. IV, tit. 1, De los esponsales y matrimonios, no. 7 .

107 Martínez de Zuñiga, Estadismo de las Islas Filipinas, 163-164. 
provincial councils in all Spanish territories. ${ }^{108}$ Although promulgated in the Philippines, the conciliar decrees were never ratified, neither by the Spanish Crown nor by the Holy See. The synod was held two years after the Council. Like the Council, its decrees were published without approval of colonial civil authorities; thus, they were also not ratified. The conciliar decree on marriage recapitulated, among other aspects, the perceived status of the customs that ecclesiastical authorities wished to temper. The scenario presented, which relied heavily on pre-conciliar reports, did not vary much from the earlier observations recorded in the handbooks for clergy as well as in civil and ecclesiastical laws. ${ }^{109}$ As Schafer Williams noted, the aforementioned decree gives "a picture of the conflict between immemorial Philippine practices and the Christian requirements".110

The first four canons under the decree on marriage dealt with dote and servicio personal (servitium personale). The Council acknowledged the "deep roots" of the tradition of brideservice. Although it was forbidden it had not been eradicated as the natives found ways to avoid it coming to the attention of parish priests. The Council was concerned with invalid marriages resulting from canonical impediments, particularly those arising from the groom's illicit relationships with the bride's sisters. It entrusted parish priests with the strict duty of eliminating servicio personal and investigating cases of violation; absent any canonical impediments, they were also to facilitate marriage for engaged couples to avoid delays and thereby prevent premarital relations and cohabitation. The Council also declared that the bride's parents, when proven culpable, should restitute to the groom whatever he had given them by way of service and imposed on them the penance of declaring their guilt for three days in church. Similarly, pasusu, the sum of money given to the bride's mother, was condemned with the corresponding penance and restitution. ${ }^{111}$ The decree on the annual episcopal visitation determined that one of the matters of inquiry in relation to marriage was whether the traditional brideservice and gift-giving persisted. ${ }^{112}$

108 Schumacher, "The Manila Council of 1771", 120-124; Williams, "The First Provincial Council of Manila", 39-40, 46-47.

109 See the report of the Franciscan Fr. Maceyra (Pérez, "Informe del P. Francisco Antonio Maceyra"). For Augustinian reports, see Pérez, Relaciones Agustinianas de las razas del norte de Luzon, 249, cited in Sison, "The First Philippine Provincial Council", 48.

110 Williams, "The First Provincial Council of Manila", 45.

111 Bantigue, The Provincial Council of Manila, 121-122; Actio v, tit. ii, decr. 7, De sacramento matrimonii, cans. 1-4. According to the Council, bigay-kaya was a custom peculiar to Chinese mestizos. The extent to which the practice had become predominantly identified with that ethnic group has yet to be verified.

Bantigue, The Provincial Council of Manila, actio II, decr. 1, De visitatione annua, can. 5,192 . 
The Synod of Calasiao approached the same issues in a more benign pastoral manner, emphasizing the sanctity of the sacrament of marriage for which the chastity of the bride was of key importance. Preaching and spiritual guidance were to be the principal means for explaining the doctrine on the sacrament. To avoid delaying marriages, the Synod instructed the natives and their parents to inform the parish priest of their engagement, after which the priest had to ensure that the couple be wedded within a month. While the Synod likewise recognized that the inability of the groom to provide the gift to the bride's mother and grandmother was a common cause of postponement of marriage, it did not recommend doing away with the practice; instead, it suggested a reasonable, more affordable sum of 20 pesos in silver or gold for wealthy individuals and 15 for the rest. ${ }^{113}$

The discourse on dote and servicio personal by colonial authorities and the resulting normative interventions ultimately aimed at instituting Tridentine marriage, which consisted of the exchange of matrimonial consent before the parish priest and witnesses. So as not to prolong the betrothal stage, couples were urged to marry any time of the liturgical year and leave the nuptial Masses for later in the periods allowed, that is, before Advent and after Epiphany and before Lent and after the end of the Easter octave. As further facilitation, the Archbishop of Manila Miguel García Serrano (1618-1629) authorized that in visitas (remote villages) and rancherías (hamlets) nuptial blessings might be given even during the prohibited period. ${ }^{114}$ The deplored delays in weddings and cohabitation out of wedlock clearly ran contrary to the Church's endeavor to promote canonical marriage. In addition, since only Church marriage was considered legitimate, the colonial tribute lists were based on the canonical records: the number of tributaries and, among them, married couples. ${ }^{115}$ Therefore, it was in the interest of secular authorities to have marital unions in order and duly documented. Another angle from which to view the discourse is that, prior to the Council of Trent, canon law had qualified that sexual relations

113 Smith, "The Acts of the Synod of Calasiao", 104-105. This translation does not mark the division into acts, titles, decrees, and canons. The sacrament of matrimony is the fifth section under the administration of sacraments, which in turn is the third main division after those on the Catholic Faith and Christian Doctrine and on Preaching the Word of God.

114 Ortiz, Práctica del ministerio, § 7, De la administracion del matrimonio, no. 72, 23. About Archbishop Serrano's decree, see the Franciscan Ritual para la recta administracion de los Santos Sacramentos, 160.

115 A tribute amounted to ten reales with an additional one real each for the celebration of Corpus Christi, patron saint of the pueblo, and Holy Week, and another real went to the municipality. Married couples paid the whole tribute as husband and wife; unmarried males (over 20) and females (over 25) living with their parents paid half. 
after betrothal, assumed to be an expression of marital affection and intention to marry (affectio maritalis), resulted in marriage. Such intention-to prove the validity of marriage - could not be proven in the external forum although in the internal forum the truth could be established. ${ }^{116}$ The Tridentine canonical form, by requiring that marriage be solemnized publicly, had sought to eradicate clandestine marriages to which the pre-Tridentine understanding of marriage applied. ${ }^{117}$

The next major intervention by civil authorities with regard to these issues came in the form of the Pragmática Sanción of 23 March 1776 and its extension, the Real Cédula of 7 April 1778, applied through the resolution (Real Acuerdo) of the Audiencia of Manila dated 21 January $1781 .{ }^{118}$ Essentially the decree sought, on the one hand, to safeguard parental authority over their children's marriage-particularly to ensure equality of status-represented by their permission and, on the other, the children's freedom to marry in the face of unreasonable parental objection. Such parental opposition could derive from personal interests, particularly material advantages, resulting in forced marriages, thus undermining the sacramental meaning of matrimony. This rationale strongly resonated in the Philippines. Not only did the Audiencia exhort the clergy to dissuade native women from marrying "recent converts to Catholicism from among Negroes, Malabarese, and Chinese", who were perceived as potentially exerting harmful influence on families and communities, but it also reminded the clergy to uproot the practice of brideservice as a way of enforcing the aims of this new law: "to be avoided are the unchaperoned meetings of unmarried persons, the detestable interest of parents, and the evil results of ill-fated marriages and much prostitution".119

In his commentary on these laws, the Franciscan Pitarque clearly wrote from a pastoral perspective. With his years of experience as parish priest of towns east of Manila, in the present-day province of Rizal, he heartily agreed with the Audiencia and the king's intention to remove obstacles to marriage and to prevent forced marriage. He observed that women were more often victims of the latter, owing to the benefits received from the gifts and brideservice. Parents arranged their daughter's marriage without asking her opinion, while she in turn carried on a clandestine relationship with the man she

\footnotetext{
116 Murillo Velarde, Curso de derecho canónico, lib. 4, tit. 1, De los esponsales y matrimonios, no. 8 .

117 Latasa, "Matrimonios clandestinos", 22-23.

118 APAF 147/1. This is a printed copy of the three concatenated laws. See Garcia, "Particular discipline on marriage", 13-14.

119 APAF 147/1, Real Acuerdo, Audiencia de Manila, 21 January 1781, no. 3.
} 
loved and revealed it only shortly before the wedding. This kind of situation rarely led to a happy outcome: either litigation ensued, as the suitor who had rendered service demanded restitution, or the woman gave in to her parents' wishes but was unfaithful to her husband. Pitarque strongly defended the royal decree's provision for non-elite indigenous people, requiring only the consent of parents and elders in general, and in their absence, of the doctrinero or parish priest. It was more lenient relative to the rules for Spaniards and the indigenous elite, which stipulated a series of individuals with moral authority who could substitute for parents. He was wary of the self-interest of the woman's relatives who, because they enjoyed the gifts and service of another man, might withhold their permission for her to marry the man she preferred. In his zeal to defend ecclesiastical jurisdiction over marriage, Pitarque selectively focused on the provision that those who married without the required permission would suffer the penalty of ineligibility for public office, even if it pertained to their lineage, up to the fourth generation. He took it to mean that they did not need to settle their situation before the secular authority that the Real Acuerdo had actually stipulated. He insisted on the spirit of the law to reduce hindrances to legitimate marriage and, as corollary, to reduce occasions for illicit relationships and cohabitation. ${ }^{120}$

\section{7}

\section{Conclusion}

In the earliest Spanish accounts on indigenous society and culture, the term dote was used to denote the indigenous practice of bugay/bigay-kaya. European appreciation of the practice was essentially comparative, noting immediately that the indigenous custom was opposite to European usage; at the same time, like in Europe, it was the crucial transaction-involving the transfer of goods and services-in negotiating marriage. Another major difference was the destination and function of the dote. That it went to the parents, instead of serving the married couple directly, was key in introducing the language of purchase that eventually predominated. When the Jesuit authors from the period of contact began to compare the practice to that of other civilizations, they likened it to a commercial transaction and thereby implied the commodification of the bride. Nineteenth-century Filipino nationalists considered this perception derogatory and sought to defend their ancestors as civilized people who treated their women with respect and recognized their pivotal place in

$12 \mathrm{O}$ AFIO, $5^{2} / 3^{2}$, fols. $2 \mathrm{~V}$ and $4 \mathrm{r}$. 
kinship groups, thus explaining the cultural meaning of these normative practices not far from the findings of contemporary anthropology. ${ }^{121}$

Book 6, title 1, law 1 of the Recopilación de las leyes de Indias resonated with the aforementioned perspective: "Indians cannot sell their daughters into marriage". ${ }^{122}$ In this law, Church prelates in the Philippines found the basic articulation of a concern they shared as guardians and promoters of Tridentine marriage. The Guatemaltecan social classes to which it referred proved congruent with those in the Philippines and a simple substitution of terms was made in the local versions, literally a case of legal translation. The various ordinances issued by civil and ecclesiastical authorities in the 18th century echoed the rhetoric of this law while elaborating on its damaging moral consequences. The customs in question were seen to foster canonical impediments to marriage and undermine Christian matrimonial values, particularly those concerning fidelity to one's spouse and sexual morality. The law consistently aimed at defending freedom of marriage, especially women's, as expressed in free consent which comprised the essence of marriage. The shared interest of public authorities in promoting canonical marriage as the only valid form reveals the perceived importance of the stabilizing function of marriage in the colonial order.

Civil and ecclesiastic rules and ordinances converged in the intention and efforts to eliminate those practices. Penalization fell mainly under secular jurisdiction, although its role in settling contentions about these material aspects of pre-matrimonial arrangements is yet to be more distinctly established given the lack of documentation. Additionally, while on the parish level the doctrinero and parish priest, in collaboration with indigenous community leaders, played a critical role in implementing the rules, questions remain as to which sets of factors affected their efficacy in different localities. The continuance of these indigenous marriage institutions points to different levels of enforcement, which in turn might have depended on the degree of understanding of the socioeconomic meaning of those practices and the limits of compromise.

In matrimonial litigation before ecclesiastical courts, the presence and importance of indigenous traditions was not lost on the ecclesiastical judges, and much less on the natives. On a fundamental level, they served as proof of willingness to marry. They were also presented as evidence of betrothal to accompany demands for the fulfillment of marriage promises, particularly on the part of the men who had invested time, labor, and material resources to

121 Paterno, Los tagalog, lib. 1, 35; lib. 2, 18; Rizal, Sucesos de las Islas Filipinas, 301, footnotes 1 and 5 . 
ratify their commitment. In judicial proceedings, mention of actual practice of bugay/bigay-kaya was given freely as evidence and was not punished. In effect, native agency was able to integrate these indigenous practices into the new Catholic matrimonial order, cognizant of the similarity of functions with comparable Spanish institutions despite some divergence in meanings.

The consistent translation of bugay/bigay-kaya to dote was the solution Spanish magistrates and scholars found to make a customary practice that was at once alien and familiar fit within the Spanish socio-juridical framework. Dote was the accepted analogue between the 16th and 18th centuries, to which Paz's translation of bugay/bigay-kaya as arras seems to have been an isolated case. The conceptual clarification attempted by Paz to sort out the normative encounter appears to go against the grain of the prevailing juridical terminology in the Philippines. Considering the tenacity of indigenous matrimonial normativity, Bishop González's radical attempt to adapt the meaning and purpose of dote to its European usage seems quixotic. While the clergy's immersion in native communities afforded them a better understanding of local usages in the context of family dynamics, community values, and gender roles, their pastoral duty obliged them to negotiate between the regulated continuance of indigenous normative practices and the enforcement of canonical marriage. The public normative discourse altogether left out the sociocultural meanings either by choice or out of sheer lack of insight. The position that the Synod of Calasiao adopted, as early as the latter part of the 18th century, would seem to be the most understanding of the critical importance of bugay/bigay-kaya in establishing the interrelated spheres of marriage, status, and family alliances. It conceded to the strength of native institutions while seeking ways to mitigate the effects detrimental to canonical marriage. The Catholic matrimonial order in the colonial Philippines continually attempted to bridge the gap, to the extent possible, between Tridentine rules and doctrines and indigenous practices.

\section{Bibliography}

\section{Manuscripts}

Archdiocesan Archives of Manila (AAM), Informaciones matrimoniales, Box 14.A.2, fold. 4, Demanda puesta por Ygnacio Flores contra Nicolasa Pagtachan sobre palabra de Casamiento, 1760 .

Archdiocesan Archives of Manila (AAM), Informaciones matrimoniales, Box 14.A.3, fold. 1, Demanda de Lucia Bernarda natural del Pueblo de Lumbang de la Provincia de la Laguna de Bay sobre esponsales con Alonso Estacio assimesmo natural y principal en dicho Pueblo, 1773 . 
Archdiocesan Archives of Manila (AAM), Informaciones matrimoniales, Box 14.A.3, fold. 3, Expediente seguido por Patricio Xavier natural del Pueblo de Taguic, sobre trato de casamiento que tiene contrahido con Maria Candelaria, 1775.

Archdiocesan Archives of Manila (AAM), Informaciones matrimoniales, Box 14.A.3, fold. 4, Vicente Hernandez contra Maria Rita de Rivera. Macabebe, Pampanga, 1777.

Archdiocesan Archives of Manila (AAM), Informaciones matrimoniales, Box 14.A.3, fold. 12 (a), Presentacion de Ygnacia de Sta Maria en que solicita se le ponga en livertad a su hija Maria de la Concepcion, que se halla depositada en las casas de las Recogidas por remision que hizo el Parroco del Pueblo de Baras Fr Casimiro Pitarque de su persona con motivo del trato de casamiento que con ella tiene celebrado con un nombrado Servando de los Santos, 1782 .

Archdiocesan Archives of Manila (AAM), Informaciones matrimoniales, Box 14.A.3, fold. 12 (b), Presentacion de Juan Perez Principal del Pueblo de Malate sobre el Matrimonio que tiene pactado su hijo Florentino Prez con una nombrada Juliana, 1782.

Archdiocesan Archives of Manila (AAM), Informaciones matrimoniales, Box 14.A.3, fold. 13, Don Manuel Constantino contra Estevan de los Santos, 1783.

Archdiocesan Archives of Manila (AAM), Informaciones matrimoniales, Box 14.A.3, fold. 14, Expediente que sigue Geronimo Bernabe del Pueblo de Sta. Cruz de Malabon sobre la suspension del Matrimonio de su hija Maria Bernabe, 1784.

Archivo Franciscano Ibero-Oriental (AFIO), 88/40, Ordenanzas circuladas por el Alcalde mayor de Bulacan para el buen gobierno de los pueblos, 1733 .

Archivo Franciscano Ibero-Oriental (AFIO), 52/32, Parecer sobre las dudas de Reales Cédulas y acuerdos en orden al casamiento de los indios, 1781.

Archivo Provincial de los Agustinos Filipinos (APAF), Real Acuerdo, Audiencia de Manila, 21 January 1781.

Archivo Provincial de los Dominicos (Avila) (APD), 1/79, Pangasinan 9, doc. 7, Asuntos civiles de alcaldes y de. los pueblos de Pangasinan, y Miscelanea de otros documentos, fols. 171r-171v.

Archivo de la Universidad de Santo Tomas (AUST), Libro 27, fols. 152r-159r, Dos pastorales del Ilmo. Sr. D. Fr. Miguel García.

Archivo de la Universidad de Santo Tomas (AUST), Libro 27, fols. 179-26o, Pastoral del Sr. Arévalo, Obispo de Nueva Cáceres, sobre las ordenanzas y edictos en dicho obispado.

Archivo de la Universidad de Santo Tomas (AUST), Libros 6o, fols. 133-134, Decreto del Gobernador prohibiendo que los indios casandos trabajen en casa de los padres de las novias.

Archivo de la Universidad de Santo Tomas (AUST), Pangasinan 3, rollo 50, no. 14, fols. 106r-109r, Quejas de un alcalde sobre intrusion en materias civiles por parte de los parrocos de Pangasinan. 


\section{Printed Sources}

Alzina, Francisco Ignacio, Una ethografía de los Indios Bisayas del Padre Alzina, ed. Yepes, Victoria, Madrid 1996.

Chirino, Pedro, Relacion de las Islas Filipinasy de lo que en ellas han trabajado los padres de la Compañia de Iesus, Rome 1604: Estevan Paulino.

Colin, Francisco, Labor evangelica, ministerios apostolicos de los obreros de la Compañia de Iesus, fundacion, y progressos de su Provincia en las islas Filipinas, Madrid 1663: Ioseph Fernandez de Buendia.

Díaz, Casimiro, Parrocho de Indios instruido idea de un perfecto pastor copiada de los SS. PP. Y Concilio. Con la resolución de las principales deudas que en la administracion de los Sacramentos se ofrecen à cerca de los Indios, Manila 1745: Imprenta de la Compañía de Jesús.

Extracto de las Leyes del Fuero Juzgo de Juan de la Reguera Valdelomar, Madrid 1798: Imprenta de la viuda e hijo de Marín (facsimile, Madrid 2015).

Governors Corcuera (1642), Cruzat y Góngora (1696), and Raón (1768) (Comp.), “Ordinances of Good Government”, in Blair, Emma H. and A. Robertson, James A. (eds.), The Philippine Islands, 1493-1898, vol. 50, Mandaluyong 1973, 191-264.

Landa, Fray Diego de, Relación de las cosas de Yucatan, ed. Prage, Christian, Mexico City 1959 .

López Gregorio, Las Siete Partidas, vol. 2, Salamanca 1555: Andrea de Portonariis (facsimile, Madrid 2011).

Luarca, Miguel de, "Tratado de las Yslas Philipinas en que se contiene todas las islas y poblaçones que estan reduçidas al servicio de la Magestad real del rey don Phelipe, nuestro Señor", in Gorriz Abella, Jaume (ed.), Filipinas antes de Filipinas. El archipiélago de San Lázaro en el siglo XVI, Madrid 2010, 29-92.

Martínez de Arizala, Pedro de la Santísima Trinidad, Carta pastoral, Manila 1751.

Martínez de Zuñiga, Joaquín, Estadismo de las Islas Filipinas, o mis viajes por este país, vol. 1, ed. Retana, W. E., Madrid 1893.

Mentrida, Alonso de, Diccionario de la lengua bisaya, hiligueina y haraya de la Isla de Panay, Manila 1841: Imprenta de D. Manuel y de D. Felis Dayot.

Morga, Antonio de, Sucesos de las Islas Filipinas, ed. Perujo, Francisca, Mexico City 2007.

Murillo Velarde, Pedro, Curso de derecho canónico hispano e indiano, ed. Carrillo Cázares, Alberto, Zamora, Michoacán 2004.

Ortiz, Tomás, Práctica del ministerio que siguen los Religiosos de N.P.S. san Augustin en Philippinas, Manila 1731: Convento de Nuestra Señora de los Ángeles.

Paterno, Pedro Alejandro, Los tagalog, Madrid 1894.

Paz, Juan de, Consultas y resoluciones varias theologicas, jurídicas, regulares, y morales, Seville 1687: Thomas López de Haro.

Pérez Martín, Antonio (ed.), Fuero Real de Alfonso el Sabio X, Madrid 2015. 
Recopilacion delas leyes destos reynos hecha por mandado... del Rey don Philippe segundo... : contienense... las leyes hechas hasta fin del año de mil y quinientos y sesenta y ocho, excepto las leyes de partida y del fuero y del estilo, y tambien van en el las visitas de las audiencias, Alcalá de Henares 1569: Andres de Angulo.

Recopilacion de leyes de los reynos de las Indias mandadas imprimir, y publicar por la magestad catolica del rey Don Carlos II nuestro señor: va dividida en quatro tomos, con el indice general, y al principio de cada tomo el indice especial de los titulos, que contiene, vol. 2, Madrid 1791: Viuda de D. Joaquin Ibarra (repr. Madrid 1998).

Río, Manuel del, Instrucciones morales y religiosas para el govierno, direccion y acierto en la nuestros ministerios que deben observar todos los religiosos de esta nuestra Provincia del Santo Rosario de Filipinas del Orden de Predicadores, Manila 1739: Imprenta de Santo Thomas.

Ritual para la recta administracion de los Santos Sacramentos y demas funciones Parochiales, Sampaloc (Manila) 1756: Imprenta del Convento de Nuestra Señora de Loreto.

Rizal, José, Sucesos de las Islas Filipinas por el Doctor Antonio de Morga, obra publicada en Méjico el año de 1609 nuevamente sacada a luz y anotada por José Rizal, Manila 1961.

Salazar, Vicente de, Historia de la Provincia de el Santísimo Rosario de Filipinas, China y Tunking, de el Sagrado Orden de Predicadores. Tercera parte en que se tratan los sucessos de dicha Provincia desde el año de 1669 hasta el de 1700, Manila 1742: Colegio de Santo Tomas.

San Antonio, Juan Francisco de, Chronicas de la Apostolica Provincia de S. Gregorio de Religiosos Descalzos de N.S.P. S. Francisco en las Islas Philipinas, China, Japon. Parte primera, Manila 1738: Imprenta de N. S. de Loreto.

San Antonio, Francisco, Vocabulario tagalo. Tagalog-Spanish Dictionary, ed. Postma, Antoon, Quezon City 2000.

Tovilla, Martín Alonso, Relaciones histórico-descriptivas de la Verapaz, el Manche, Lacandon, ed. Prage, Christian, Guatemala City 196o.

\section{Literature}

Anderson, Siwan, "The Economics of Dowry and Brideprice", in Journal of Economic Perspectives 21:4 (2007): 151-174.

Bantigue, Pedro, Provincial Council of Manila of 1771 (PhD Dissertation), Washington 1957.

Birriel Salcedo, Margarita María, "Mujeres y matrimonio: Senetido y significación de las arras en la Corona de Castilla", in López Beltrán, María Teresa, Marion Reder Gadow and María Isabel del Val Valdivieso (eds.), Historia y género: imágenes y vivencias de mujeres en España y América (siglos XV-XVIII), Málaga 2007, 69-100. 
Bossen, Laurel, "Toward a Theory of Marriage: The Economic Anthropology of Marriage Transactions", in Ethnology 27:2 (1988): 127-144.

Botticini, Maristella and Aloysius Siow, "Why Dowries?", in The American Economic Review 93:4 (2003): 1385-1398.

Camacho, Marya, "Mirando las cosas de cerca": Indigenous Marriage in the Philippines in the Light of Law and Legal Opinions (17th-18th Centuries)", in The School of Salamanca: A Case of Global Knowledge Production, Leiden 2021.

Cannell, Fenella, Power and Intimacy in the Christian Philippines, Quezon City 1999.

Costa, Horacio de la, "Review of Pedro N. Bantigue, The Provincial Council of Manila of 1771", in Philippine Studies 7:1 (1959): 120-124.

Donoso, Isaac (ed.), Boxer Codex. A Modern Spanish Transcription and English Translation of Sixteenth-Century Exploration Accounts of East and Southeast Asia and the Pacific, Quezon City 2016.

Evans-Pritchard, Edward E., “An Alternative Term for 'Bride-Price”, in Man 31 (1931): 36-39.

Garcia, Excelso, "Particular Discipline on Marriage in the Philippines during the Spanish Regime", in Philippiniana Sacra 8 (1973): 7-88.

Goody, Jack, "Bridewealth and Dowry in Africa and Eurasia", in Goody, Jack and S. J. Tambiah (eds.), Bridewealth and Dowry, Cambridge Papers in Social Anthropology, no. 7 (1973): 1-58.

Gonzalbo Aizpuru, Pilar, "Las cargas del matrimonio. Dotes y vida familiar en la Nueva España”, in Gonzalbo Aizpuru, Pilar and Cecilia Rabell Romero (eds.), Familia yvida privada en la historia de Iberoamérica, Mexico City 1996, 207-226.

Hidalgo Nuchera, Patricio, Los autos acordados de la Real Audiencia de las Islas Filipinas de 1598 y 1599, Madrid 2012.

Javellana, René B., "The Jesuits and the Indigenous Peoples of the Philippines", in O'Malley, John, S.J., Gauvin Alexander Bailey, Steven J. Harris, and T. Frank Kennedy, S.J (eds.), The Jesuits: Cultures, Sciences, and the Arts, 1540-1773, Vol. 1, Toronto 1999, 418-438.

Junker, Laura Lee, Raiding, Trading, and Feasting: The Political Economy of Philippine Chiefdoms, Quezon City 2000.

Korth, Eugene H. and Della M. Flusche, "Dowry and Inheritance in Colonial Spanish America: Peninsular Law and Chilean Practice", in The Americas 43:4 (1987): 395-410.

Latasa, Pilar, "Matrimonios clandestinos y matrimonios secretos", Diccionario Histórico de Derecho Canónico en Hispanoamérica y Filipinas, Max Planck Institute for European Legal History Research Paper Series, No. 2019-11.

Mijancos Gurruchaga, Laliana, La igualdad entre el varón y la mujer casada en el Derecho español, con especial atención al actual Código Civil de 1889. Aspectos doctrinales y filosófico jurídicos (PhD Dissertation), Palma de Mallorca, 2014. 
Owen Hughes, Diane, "Del precio de la novia a la dote en la Europa mediterránea", in Arenal. Revista de Historia de las Mujeres 8:2 (2001): 237-289.

Pérez, Lorenzo, "Fr. Juan de Plasencia y sus relaciones sobre las costumbres que los filipinos observaban en la tramitación de sus juicios civiles y criminales antes de la llegada de los españoles a Filipinas", in Archivo Ibero-Americano 40 (1920): 52-75.

Pérez, Lorenzo, "Informe del P. Francisco Antonio Maceyra sobre varios puntos de los que convendrá tratar en el Concilio provincial de Manila (Paquil, Febrero 1771)", in Archivo Ibero-Americano 30 (1928): 377-397.

Pérez, Ángel, Relaciones Agustinianas de las razas del norte de Luzon, Parte décima, Informes que se remitieron al Señor arzobispo para el concilio de Manila sobre aniterías, supersticiones y otros abusos de los Indios por Fr. Sebastián Moreno y Fr. Eusebio Polo, Manila 1904.

Phelan, John Leddy, The Hispanization of the Philippines. Spanish Aims and Filipino Responses, Madison (Wisconsin) 2011.

Rubiés, Joan-Pau, "The Spanish Contribution to the Ethnology of Asia in the Sixteenth and Seventeenth Centuries", in Renaissance Studies 17:3 (2003): 418-448.

Scott, William Henry, Barangay: Sixteenth-Century Philippine Culture and Society, Quezon City 2015.

Sison, Raphael Magno, The First Philippine Provincial Council (1771). Its Controversies as Reflected in the Unpubished Documents of Its Preparatory Congregations (PhD Dissertation), Rome 1979 .

Smith, Philip F., "The Acts of the Synod of Calasiao, 1773", in Philippiniana Sacra 5:13 (1970): 65-107.

Tambiah, Stanley J., "Bridewealth and Dowry Revisited: The Position of Women in Sub-Saharan Africa and North India", in Current Anthropology 30:4 (1989): 413-435.

Testart, Alain, "Reconstructing Social and Cultural Evolution: The Case of Dowry in the Indo-European Area", in Current Anthropology 54:1 (2013): 23-50.

Vroklage, Bernard, "Bride Price or Dower", in Anthropos 47:1-2 (1952): 133-146.

Williams, Schafer, "The First Provincial Council of Manila, 1771", in The Jurist 13 $\left(1955^{-56)}: 33^{-47}\right.$. 